\title{
Effect of Biophilic-Horticultural Education on Children's Multisensory Enhancement
}

\author{
Hyeran Kwack* and Meeyeoun Chae \\ Department of Science and Technology Education for Life, Seoul National University of Education, Seoul 06639, Korea
}

\begin{abstract}
This study aimed to develop a program that can be linked to gardening education activities in elementary students' curriculums and creative experience learning courses, and to apply the developed program to 6th graders in an elementary school located in Seoul. Research was conducted in a large category called biophilia, which named the instinct of human nature and nature throughout the research. The curriculum revised in 2015 was selected for the purpose of the garden education program based on the objectives and contents of the unit, and for the purpose of the class. In the process of developing and implementing the program, experience properties and elements were divided into direct and indirect experience of nature, including shapes and forms found in nature, air, water, plants, weather, animals, and natural materials. The results showed that the biophilic horticultural education program was effective in promoting students' multi senses. In the case of the experimental group, all the multi-sensory areas showed statistically significant differences, especially in the area of environmental literacy, environmental effect and emotional balance including plant cultivation knowledge. There was a relatively smaller difference in the dietary effect area than other areas because of no directional dietary program was included in the developed program. As a result, first, it is expected that the data can be utilized on site as a program or place of activity for students in upper grades. Second, it will be necessary to develop a more diverse program using other biophilic elements that were not covered in this study in order to maximize the effects of biophilic education.
\end{abstract}

Keywords: environmentally friendly attitude, human nature, multi-sensitive angles, space-based experience

\section{Introduction}

Biophilia was first coined by Edward Osborne Wilson in 1979, and the term is the combination of "bio (life)" and "-philia (brotherly love)," meaning "love of life" (Wilson, 1994). The biophilia hypothesis has been widely used as a fundamental theory under which humans have an innate tendency to "love life" and restore a balance by seeking connections with nature in the process of urbanization. In particular, he suggested in his recent studies that communion with indoor gardens and green spaces that view nature as an important concept can bring about positive emotions and have positive effects not only directly on natural elements but also works of art that depict nature such as paintings, sculptures, and various activities involving natures, contributing to the reduction of depression and stress (Wilson, 1994). Kellert et al.

This study was supported by the "Research Between the Fields of Elementary Education" of the Subject Matter Education Joint Research of Seoul National University of Education in 2018.

Received: November 19, 2018, Revised: November 28, 2018, Accepted: December 6, 2018

First author: Hyeran Kwack, E-mail: kwack621@snue.ac.kr, ORCID: 0000-0001-5659-570X

*Corresponding author: Hyeran Kwack, E-mail: kwack621@snue.ac.kr, ORCID: 0000-0001-5659-570X

2018 by the Society for People, Plants, and Environment. This is an Open Access article distributed under the terms of the Creative Commons Attribution Non-Commercial License (http://creativecommons.org/licenses/by-nc/4.0/) which permits unrestricted non-commercial use, distribution, and reproduction in any medium, provided the original work is properly cited. 
(2008) also reported that indirect natural elements that remind people of nature such as paintings and images as well as direct natural elements are effective in reducing stress. In line with that, many education facilities and community centers around the world have actively employed biophilic design, and have maintained green spaces, landscape gardens and other facilities in school environments to ensure students can experience natural elements and participate in programs involving nature and gardening activities using these environments, having various educational effects (Yoon and Lee, 2016). In particular, biophilic design introduces a variety of ecological activities that utilize physical environments, and can be utilized as an environment for healing that positively affect humans' multisensory elements, that is, wellbeing, sensory and psychological stability, resilience and health (Yoon, 2013). However, today's classrooms in elementary schools in urban areas and urban environments do not provide the utility of biophilic design, and they are rather staying in an environment that can produce students who do not care about nature and are ecologically illiterate (Jee, 2015). For this reason, biophilic programs have been considered as an alternative to a conventional one-time horticultural program in order to obtain various educational effects by actively utilizing biophilic elements and school environments that students can explore and experience in person (Yoon, 2013). Against this backdrop, this study aimed to analyze biophilic experience elements and designs that can be commonly found within schools, to develop biophilic horticultural programs by connecting them to the curriculum revised in 2015 and to measure the expected educational effects of the programs applied to children.

\section{Research Methods}

\section{Subjects and Procedure}

In this study, two 6-grade classes (24 students per class) in S elementary school located in an apartment area in Seoul were selected, and one 6-grade class that was homogeneous with the selected students above in terms of their residential type and prior educational experience was selected as a control group. The procedure shown in Table 1 was adopted to identify the effects of biophilic horticultural education activities and experiences on the multisensory enhancement of children. The research procedure in this study was composed of stages of planning and preparation, implementation and arrangement, and each stage was composed of sub-items including developing research questions, selecting analysis tools, implementing on site, pre and post-experiment questionnaire surveys, analyzing surveyed data and setting follow-up research directions (Table 1).

\section{Experimental Design}

The experiment used in this study was designed as shown in Table 2.

\section{Measuring Tools and Methods}

Measuring tools used in this study were selected based on various earlier studies in connection with the content of horticultural education and educational goals as shown in Table 3 and 4 . They were, in turn, divided into sub-items for the purpose of this study, and a total of 25 questions were developed. Each question was answered on a 5-point Likert scale as follows: 'strongly agree (1 point)', 'agree ( 2 points)', 'neutral (3 points)', 'disagree ( 4 points)' and 'strongly disagree (5 points)' (Table 4). The lower the combined score of the entire questions, the higher the biophilic score of the cognitive, emotional and psychomotor domains related to horticulture. The Cronbach's alpha of each sub-item ranged between .69 and .76, showing high reliability. Using the developed questionnaire, pre and post-experiment questionnaire surveys were conducted, and the collected data were analyzed using i-STATistics 2.0. 
Table 1. Research process

\begin{tabular}{|c|c|c|c|}
\hline Step & Procedure & Contents & Period \\
\hline \multirow{3}{*}{$\begin{array}{l}\text { Planning and } \\
\text { preparation }\end{array}$} & $\begin{array}{l}\text { Theory \& background } \\
\text { exploration }\end{array}$ & Resource accumulation and categorizing through reference research & \multirow{3}{*}{$\begin{array}{c}2016.11 \sim \\
2017.2\end{array}$} \\
\hline & $\begin{array}{l}\text { Selecting research } \\
\text { problems }\end{array}$ & Establishment of research planning based on horticultural programs & \\
\hline & Selecting research tools & Collecting and selecting questionnaire with horticultural activities & \\
\hline \multirow{9}{*}{ Implementation } & $\begin{array}{l}\text { Reorganization of } \\
\text { educational process }\end{array}$ & $\begin{array}{l}\text { Recomposition of horticultural programs through analysis of } 6 \\
\text { grader's contexts and creative experience activity }\end{array}$ & \multirow{9}{*}{$\begin{array}{l}2017.3 \sim \\
2017.12\end{array}$} \\
\hline & $\begin{array}{l}\text { Implementation of } \\
\text { pre-questionnaire }\end{array}$ & Implementation of pre-questionnaire and its results & \\
\hline & \multirow{3}{*}{$\begin{array}{l}\text { Analyzing program } \\
\text { elements }\end{array}$} & Analyzing of concept of biophilia & \\
\hline & & Analyzing of biophilic design elements & \\
\hline & & Analyzing of horticultural education activity & \\
\hline & $\begin{array}{l}\text { Analyzing of pre-research } \\
\text { of horticultural program }\end{array}$ & Discussion of horticultural education activity based reference & \\
\hline & $\begin{array}{l}\text { Field implementation of } \\
\text { horticultural programs }\end{array}$ & Composition and implementation of horticultural program & \\
\hline & $\begin{array}{l}\text { Implementation of } \\
\text { post questionnaire }\end{array}$ & $\begin{array}{l}\text { Implementation of post-questionnaire and } \\
\text { selection of its results }\end{array}$ & \\
\hline & $\begin{array}{l}\text { Supplementaion of } \\
\text { horticultural program }\end{array}$ & $\begin{array}{l}\text { Implementation of program and additional } \\
\text { selective questionnaire }\end{array}$ & \\
\hline \multirow{2}{*}{ Arrangement } & $\begin{array}{l}\text { Analyzing of results } \\
\text { of questionnaire }\end{array}$ & Analyzing statistics of questionnaire results & \multirow{2}{*}{$\begin{array}{c}2018.2 \sim \\
2018.5\end{array}$} \\
\hline & Make up of results & Arrangement of research result and writing report & \\
\hline
\end{tabular}

Table 2. Preliminary analysis of variance in interpersonal relationship tendencies among three groups

\begin{tabular}{cccc}
\hline & Pre & Post \\
\hline Treatment group & $\mathrm{O}_{1}$ & $\mathrm{X}_{1}$ & $\mathrm{O}_{2}$ \\
Control group & $\mathrm{O}_{3}$ & & $\mathrm{O}_{4}$ \\
\hline
\end{tabular}

$\mathrm{X}_{1}$ : Application of the biophilic horticultural program

$\mathrm{O}_{1}, \mathrm{O}_{2}$ : Pre-post data analysis of Treatment group(Paired t-test)

$\mathrm{O}_{1}, \mathrm{O}_{3}$ : Pre homogenity test of Treatment and Control group(Independent t-test)

$\mathrm{O}_{2}, \mathrm{O}_{4}$ : Post homogenity test of Treatment and Control group(Independent t-test)

$\mathrm{O}_{3}, \mathrm{O}_{4}$ : Pre-post data analysis of Control group(Paired t-test)

Table 3. Division of educational goal

\begin{tabular}{lcc}
\hline Domain & Division & Contents \\
\hline Cognitive & Intelligent ability and function development & Plant cultivating skills, plant division, horticulture literacy \\
Emotional & Attitude, belief, value development & Emotion, humanity, stress \\
Psych-motor & Health development and diet & Diet, environment purification \\
\hline
\end{tabular}


Table 4. List of multisensory categories in a 5-point Likert scale questionnaire

\begin{tabular}{|c|c|c|c|c|}
\hline Domain & Category & Code & Contents & Cronbach's $\alpha$ \\
\hline \multirow{9}{*}{$\begin{array}{l}\text { Cognitive } \\
\text { domain }\end{array}$} & \multirow{3}{*}{ Growth environment } & 1 & Understanding of plant watering & \multirow{3}{*}{.709} \\
\hline & & 2 & Understanding of light intensity & \\
\hline & & 3 & Understanding of water requirement & \\
\hline & \multirow{2}{*}{$\begin{array}{c}\text { Plant } \\
\text { division }\end{array}$} & 4 & Understanding of outdoor plant & \multirow{2}{*}{691} \\
\hline & & 5 & Understanding of indoor plant & \\
\hline & \multirow{4}{*}{$\begin{array}{c}\text { Increasement of } \\
\text { integrative thinking }\end{array}$} & 6 & Interest of plant refinement & \multirow{4}{*}{.764} \\
\hline & & 7 & Interest of plant art refinement & \\
\hline & & 8 & Interest of plant science refinement & \\
\hline & & 9 & Interest of people-plant relationship & \\
\hline \multirow{10}{*}{$\begin{array}{l}\text { Emotional } \\
\text { domain }\end{array}$} & \multirow{3}{*}{ Emotional stability } & 10 & Understanding of plant's healing effect & \multirow{3}{*}{.722} \\
\hline & & 11 & Refinement of plant cultivation interest & \\
\hline & & 12 & Worship of living & \\
\hline & \multirow{2}{*}{ Stress } & 13 & Relationship of leisure and plant cultivation & \multirow{2}{*}{.707} \\
\hline & & 14 & Correlation between mind stabilization and plant & \\
\hline & \multirow{5}{*}{$\begin{array}{l}\text { Humanity } \\
\text { cultivation }\end{array}$} & 15 & Correlation between sense of responsibility and plant & \multirow{5}{*}{.710} \\
\hline & & 16 & Interest of plant reservation & \\
\hline & & 17 & Interest of animal welfare & \\
\hline & & 18 & Interest of green life & \\
\hline & & 19 & Consideration of plant & \\
\hline \multirow{6}{*}{$\begin{array}{l}\text { Psycho- } \\
\text { motor domain }\end{array}$} & \multirow{3}{*}{$\begin{array}{c}\text { Environmental } \\
\text { effect }\end{array}$} & 20 & Transpiration and plant & \multirow{3}{*}{.734} \\
\hline & & 21 & Forest shower and plant & \\
\hline & & 22 & Air purification and plant & \\
\hline & \multirow{3}{*}{$\begin{array}{c}\text { Dietary } \\
\text { effect }\end{array}$} & 23 & Interest of vegetables and fruits & \multirow{3}{*}{.718} \\
\hline & & 24 & Change of eating habit & \\
\hline & & 25 & Understanding of vegetable and fruit's nutrition & \\
\hline
\end{tabular}

\section{Results and Discussion}

\section{Analysis of Biophilic Elements}

To select biophilic elements utilized as a program frame in this study, recent earlier studies on the characteristics and elements of biophilic experience (Lee and Lee, 2016) and the elements and properties of biophilic design (Yoon and Lee, 2016) were analyzed. Considering the characteristics of this study, eco-friendly design elements for elementary schools (Sim, 2008) were also included. Based on the results of analysis, biophilic elements were divided into "biophilic design classification," "biophilic experience elements," "biophilic design elements" and "biophilic planning elements" (Figure 1). "Biophilic experience elements" were divided into "direct experience of nature," "indirect experience of nature" and "experience of spaces and places" (Sim, 2008). Elements under the category of "direct experience of nature" included natural light, air, water, plants, animals, perceived weather, natural landscapes and views and lighting, and elements under the category of "indirect experience of nature" included images of nature, natural materials, natural colors, natural light, imitated air conditions, shapes and forms found in nature, forms reminiscent of nature, abundant information, variability of nature, geometric shapes found in nature and biomimetics. Elements under the category of "experience of spaces and 
places" include views and hiding places, complexity, integration of the part and the whole, changing spaces, mobility and navigation (Hwang and Lee, 2015). "Eco-friendly elements" among "biophilic design elements" included color, water, air, sunlight, animals, views and landscapes, greenwalls and ecosystems, and "shapes and forms found in nature" included animal and plant motives, tree shapes, arch shape and biomimetics. "Patterns and processes found in nature" included fractal structure, supplementation and contrast, integration of the part and the whole, spaces for conversion and changes over time. "Eco-friendly relationships between humans and nature" included elements such as views and hiding places, order and complexity, changes and transformation, safety and protection, information and perception, etc. Lastly, "eco-friendly design elements for elementary schools" included "energy efficiency," "sustainability" and "creation of green environments," and "energy efficiency" included design elements such as light (natural lighting, artificial lighting), air (natural ventilation, eco-friendly materials), thermal environments (reduction of cooling and heating loads) and renewable energy (solar energy). "Sustainability" included design elements such as materials (utilization of recycled materials), waste (waste treatment) and water resources (water conservation and reuse), and "creation of green environments" included design elements such as landscaping (green buildings, green spaces, biotop, spaces for education) (Sim, 2008). The items above are briefly summarized in Figure 1.

Based on Figure 1, biophilic elements for horticultural activities in schools were re-organized as shown in Table 5. Biophilic experience elements were used as a general frame for embracing all the topics above, and they were, in turn, divided into elements, topics and educational elements (Table 5). In particular, Table 5 shows the overall biophilic elements that can be connected with school environments. This study focused on identifying various biophilic elements within schools considering the unique characteristics of the place of schools and horticultural activities, while general studies focused on the concept of biophilia and its design aspects. In particular, it was difficult to connect place and spacebased experiences with many elements considering practical circumstances, but elements like "ecological attachment to



Figure 1. Analysis of biophilic elements. 
Table 5. School environment and biophilic element connected with school environment and horticultural activity

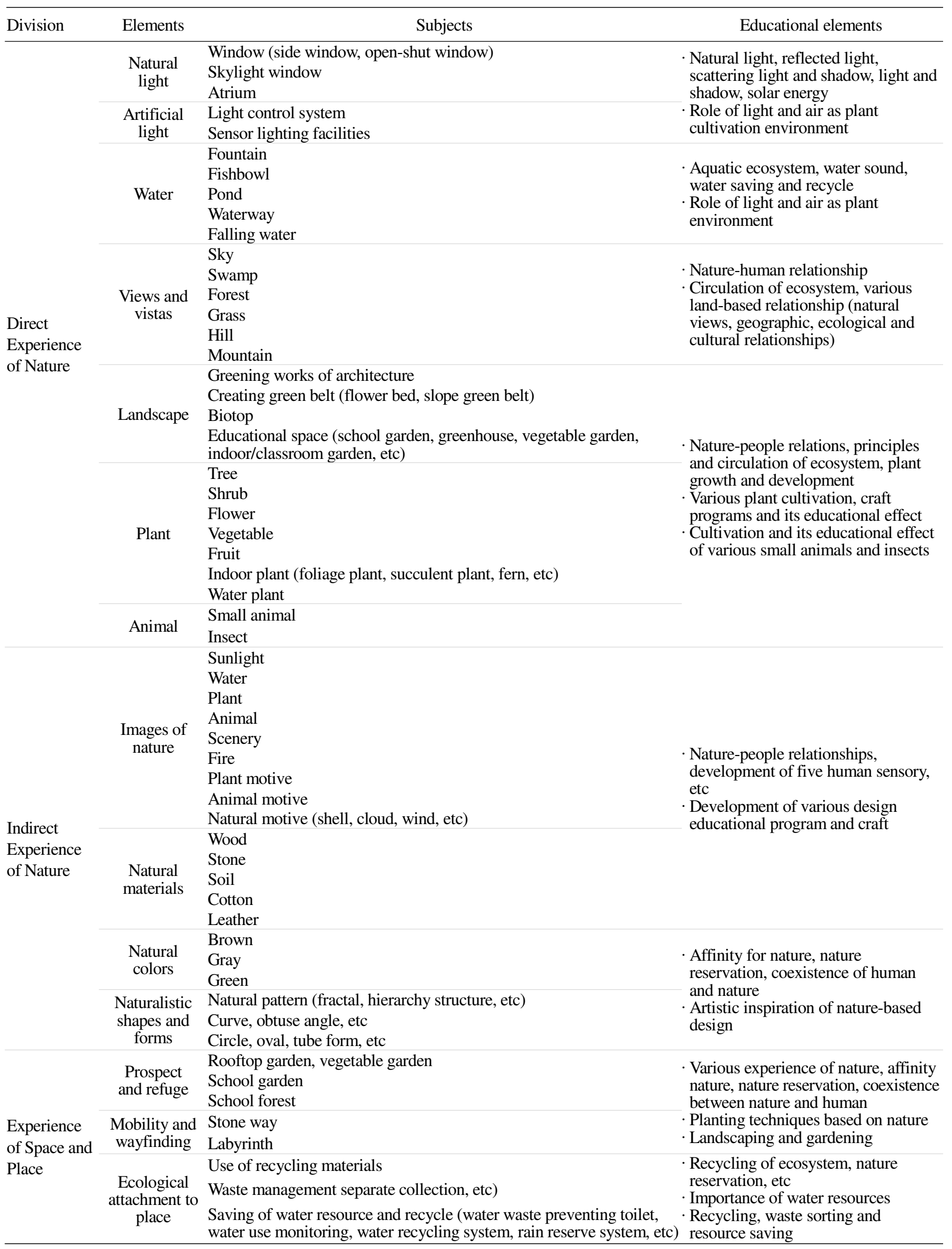


place" that was obtained in an earlier study (Sim, 2008) including the utilization of recycled materials, waste treatment, water conservation and reuse were considered as a practical and characteristic element in providing biophilic education that considers the sustainability of ecosystems (Table 5).

\section{Composition of the Biophilic Horticultural Activity Program}

Based on the biophilic elements analyzed in Table 5, related subjects and units were analyzed to provide biophilic horticultural activities within the subjects (Table 6). The results of analyzing the subjects for 4th, 5th and 6th graders showed that biophilic elements can be relatively more connected to the subjects for 6th graders such as science, art, social studies, Korean and practical arts. In particular, "direct experience of nature" was mostly related to units about science due to the characteristics of the element, and units about agriculture and horticulture in practical arts, and observation-based

Table 6. Textbook and unit connected with biophilic horticultural contents

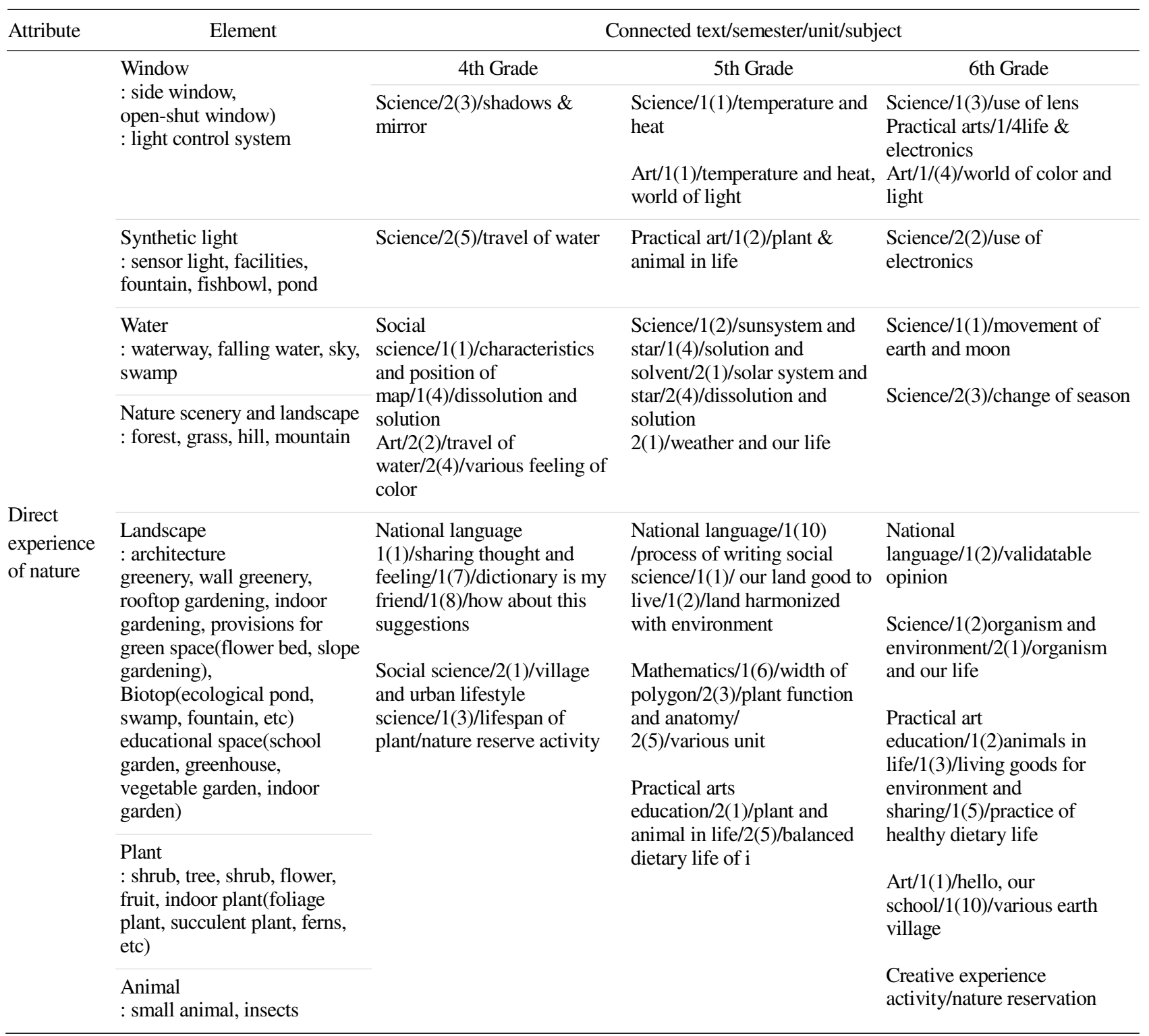


Table 6. (continued)

\begin{tabular}{|c|c|c|c|c|}
\hline Attribute & Element & \multicolumn{3}{|c|}{ Connected text/semester/unit/subject } \\
\hline \multirow{5}{*}{$\begin{array}{l}\text { Indirect } \\
\text { Experience } \\
\text { of Nature }\end{array}$} & \multirow{2}{*}{$\begin{array}{l}\text { Nature image } \\
\text { : sunlight, water, plant, } \\
\text { animal, scenery, fire, plant, } \\
\text { animal, nature motive(shell, } \\
\text { cloud, wind) }\end{array}$} & 4th Grade & 5th Grade & 6th Grade \\
\hline & & $\begin{array}{l}\text { Science/1(5)/separation of } \\
\text { mixtures/2(1)/earthquake and } \\
\text { volcano }\end{array}$ & $\begin{array}{l}\text { National language } \\
/ 1(4) / \text { thoughts of } \\
\text { works/2(4)/show the }\end{array}$ & $\begin{array}{l}\text { Mathematics/1(2)/building } \\
\text { blocks } \\
\text { Science/2(4)/combustion and }\end{array}$ \\
\hline & $\begin{array}{l}\text { Nature materials } \\
\text { : wood, stone, soil, cotton }\end{array}$ & $\begin{array}{l}\text { Art/1(1)/secrets of beauty, } \\
\text { sculpture elements/1(2)/ } \\
\text { various feelings of } \\
\text { color/1(3)/to the world of } \\
\text { observation }\end{array}$ & $\begin{array}{l}\text { Practical arts } \\
\text { education/1(1)/plant and life } \\
\text { Art/1(5)/nature with five } \\
\text { sensory }\end{array}$ & $\begin{array}{l}\text { fire extinguish } \\
\text { Art/1(2)/into the } \\
\text { scenery/1(4)design for } \\
\text { all/1(5)/hearing and watching } \\
\text { nature }\end{array}$ \\
\hline & $\begin{array}{l}\text { Natural color } \\
\text { : brown, gray, green }\end{array}$ & $\begin{array}{l}\text { Art/1(4)/to the } \\
\text { world/1(7)/joyful art in the }\end{array}$ & $\begin{array}{l}\text { Mathematics/2(2)/congruence } \\
\text { and symmetry }\end{array}$ & $\begin{array}{l}\text { Mathematics/1(4)/rate and } \\
\text { ratio/2(3)/cylinder, cone, ball }\end{array}$ \\
\hline & $\begin{array}{l}\text { Natural form and shape } \\
\text { : nature pattern(fractal, } \\
\text { hierarchical structure, shell, } \\
\text { curve, obtuse angle, oval, tube } \\
\text { form, etc) }\end{array}$ & & $\begin{array}{l}\text { Art/2(2)/exploration } \\
\text { classroom with } \\
\text { knowledge/2(3)/joyful } \\
\text { imagination garden }\end{array}$ & \\
\hline \multirow{8}{*}{$\begin{array}{l}\text { Experience } \\
\text { of space and } \\
\text { place }\end{array}$} & \multirow[t]{5}{*}{$\begin{array}{l}\text { View and hiding place } \\
\text { : rooftop garden, vegetable } \\
\text { garden, school garden, school } \\
\text { forest }\end{array}$} & $\begin{array}{l}\text { Science/1(1)/lifespan of } \\
\text { plant/1(3)/life of plant } \\
\text { creative activity/plant } \\
\text { reservation activity }\end{array}$ & $\begin{array}{l}\text { Science/1(3)/plant anatomy } \\
\text { and function } \\
\text { Mathematics/2(5)various } \\
\text { units }\end{array}$ & $\begin{array}{l}\text { Art/1(5)/hearing and watching } \\
\text { nature } \\
\text { Practical arts } \\
\text { education/1(2)/plant in life }\end{array}$ \\
\hline & & & $\begin{array}{l}\text { Practical art education/1(1)/ } \\
\text { plant and animal in } \\
\text { life/1(2)/plant growing }\end{array}$ & \\
\hline & & $\begin{array}{l}\text { Science/2(1)/life of } \\
\text { plant/2(2)journey of water } \\
\text { Art/2(1)/various plant of color }\end{array}$ & $\begin{array}{l}\text { Social science/1(2)/land } \\
\text { harmonized with } \\
\text { environment/1(1)/ Hello, our } \\
\text { school/1(12)/world of color } \\
\text { and light }\end{array}$ & $\begin{array}{l}\text { Science/2(1)/organism and } \\
\text { our life }\end{array}$ \\
\hline & & & $\begin{array}{l}\text { Practical art education/1(1)/ } \\
\text { plant and animal in } \\
\text { life/1(2)/plant growing }\end{array}$ & \\
\hline & & $\begin{array}{l}\text { National } \\
\text { language/1(3)/talking with } \\
\text { feelings }\end{array}$ & $\begin{array}{l}\text { Science/2(1)/weather and our } \\
\text { life/2(5)/nature with five } \\
\text { sensory/2(2)/animal and } \\
\text { plants in life }\end{array}$ & $\begin{array}{l}\text { Art/1(2)/into the scenery } \\
\text { Practical art } \\
\text { education/1(2)/animal in life }\end{array}$ \\
\hline & \multirow[t]{2}{*}{$\begin{array}{l}\text { Mobility and wayfinding } \\
\text { : stoneway, labyrinth }\end{array}$} & $\begin{array}{l}\text { Art/1(1)/secrets sculpture } \\
\text { elements of beauty }\end{array}$ & Art/2(1)/beauty of sculpture & $\begin{array}{l}\text { Art/1(5)/hearing and watching } \\
\text { nature }\end{array}$ \\
\hline & & Art/1(7)/interesting art in life & $\begin{array}{l}\text { Art/2(5)/nature with five } \\
\text { sensory }\end{array}$ & Science/2(2)/change of season \\
\hline & $\begin{array}{l}\text { Ecological attachment to } \\
\text { place) } \\
\text { : Use of recycling materials } \\
\text { (separating facility of } \\
\text { recycling materials), Reuse of } \\
\text { water resources (water waste } \\
\text { preventing toilet, water use } \\
\text { monitoring, water recycling } \\
\text { system, rain reserve system, } \\
\text { etc) }\end{array}$ & $\begin{array}{l}\text { National language/1(3)/public } \\
\text { facilities and citizen } \\
\text { involvement } \\
1(8) / \text { how about this } \\
\text { suggestions? } \\
\text { Science/1(5)/separation of } \\
\text { mixtures/2(2)/journey of } \\
\text { water }\end{array}$ & $\begin{array}{l}\text { Social science } / 1(2) / \text { land } \\
\text { harmonized with environment } \\
\text { Science/1(4)/dissolution and } \\
\text { solution }\end{array}$ & Art/1(4)/design for all \\
\hline
\end{tabular}


units about art were connected to the program. In particular, "indirect experience of nature" was connected with subjects including art, mathematics and Korean and related units, and "experience of places and spaces" was connected with units related to science and art (Table 6).

\section{Development and Application of the Biophilic Horticultural Program}

\section{Restructured Program for On-site Application}

Several elements were extracted from the curriculum-connected programs suggested in Table 6 to develop a curriculumbased program composed of a total of 12 sessions for on-site application. "Indirect experience of nature" and "direct experience of nature" were selected as a property for the program, but "experience of places and spaces" was not selected due to limitations in school environments. "Indirect experience of nature" was mainly composed of handicraft activities (writing a life note, making plant curtains, making a cushion with fallen leaves, making an air freshener with herbs, etc.), and "direct experience of nature" was composed of activities of directly cultivating plants (water culture, understanding biotop, making an ecosphere, etc.). Taking advantage of the characteristics of biophilia, participants were able to experience all four seasons through the activities. Unlike conventional horticultural activities, biophilic horticultural activities were designed to utilize biophilic environments and design. For instance, the indirect experience activity of "making a natural sound bell" used natural sounds as a class bell to experience natural images, and activities such as "making plant curtains" and "making a cushion with fallen leaves" used a variety of plants as a motive to make classroom curtains and cushions. In addition, the activity of "upcycling gardening" was differentiated by recycling containers and soil used when planting herbs and using food waste compost to ensure participants experience eco-friendly elements. The program for the direct experience of nature was also composed of various ecological experience activities such as "making an ecosphere," "exploring school gardens and vegetable gardens" and "understanding biotop" instead of an one-time activity of planting (Table 7). By doing so, biophilia horticultural activities were designed to be more suitable to provide education on ecology and natural environments than general horticultural activity programs (Table 7). Overseas cases such as exploring places for and placing bird houses, observing the growth of seeds and making a nature class web also seem to be committed to biophilic elements (Texas A\&M Univ, 2010).

\section{Results After Applying the Developed Program}

\section{(1) Homogeneity Test Between the Experimental Group and the Control Group}

A preliminary test was conducted on the experimental group and the control group prior to applying the program, and the results were analyzed by sub-item. The two groups were found to be homogeneous in terms of growth environments, plant classification, promotion of integrative thinking ability, emotional stability, stress, cultivation of character, environmental effects and dietary effects. This result can be attributed to the fact that the preliminary test was carried out in the beginning of the first semester among students who were the same age and had relatively homogeneous experiences of educational environments (Table 8).

(2) The Results of Pre and Post-experiment Surveys of the Control Group

Pre and post-experiment surveys were performed to examine changes in the level of horticultural knowledge, familiarity with nature and psychological stability after implementing the developed program. To examine significant differences between the experimental and control groups, t-test was performed. The control group who did not participate in the program did not show any significant difference between the results of the pre-experiment survey and those of the post-experiment survey performed after 10 months except integrative thinking ability and emotional stability (Table 9). 
Table 7. Biophilic horticultural activity connected with school class

\begin{tabular}{|c|c|c|c|c|c|}
\hline Division & Year & Session & Program & Connected subject & Biophilia element \\
\hline \multirow{8}{*}{$\begin{array}{l}\text { Indirect } \\
\text { experience of } \\
\text { nature }\end{array}$} & \multirow{8}{*}{$\begin{array}{l}\text { Year } \\
\text { round }\end{array}$} & 1 & Life note writing & National language/Science/art & Natural shape and form \\
\hline & & 2 & Making natural signal & Class management & Air/water \\
\hline & & 3 & Making a curtain with plants & Science/practical art education & Plant/weather \\
\hline & & 4 & Drawing a big tree & Art & Plant \\
\hline & & 5 & Water recycling and I & Science & Water \\
\hline & & 6 & Making plant collages with pant pictures & $\begin{array}{c}\text { Art/science/practical art } \\
\text { education }\end{array}$ & Natural materials \\
\hline & & 7 & Making a plant pot with recycling paper & Art/practical art education & Natural materials \\
\hline & & 8 & Understanding mediclinal plants & Science/practical art education & Plant \\
\hline \multirow{2}{*}{$\begin{array}{l}\text { Indirect } \\
\text { experience of } \\
\text { nature }\end{array}$} & \multirow{5}{*}{ Spring } & 0 & Upcycling garden & Dt1. & Dlo \\
\hline & & 9 & Making new cloth to pots & Euncs/alticreative expentence & FTallit \\
\hline \multirow{3}{*}{$\begin{array}{l}\text { Indirect } \\
\text { experience of } \\
\text { nature }\end{array}$} & & 10 & Making ecosphere & Practical art education/science & Water/plant \\
\hline & & 11 & Making rainbow garden & Art/practical art education & Landscape \\
\hline & & 12 & $\begin{array}{l}\text { Decorating a wicking pot with } \\
\text { airpurifying plants }\end{array}$ & Practical art education/science & Plant \\
\hline \multirow{4}{*}{$\begin{array}{l}\text { Direct } \\
\text { experience of } \\
\text { nature }\end{array}$} & \multirow{4}{*}{ Summer } & 13 & Making herb drink and canape & Practical art education & Plant \\
\hline & & 14 & Doing water culture & Practical art education/science & Water/plant \\
\hline & & 15 & Understanding biotop & Science & Light/water/plant \\
\hline & & 16 & Managing indoor garden & Practical art education/science & Light/water/plant \\
\hline \multirow{2}{*}{$\begin{array}{l}\text { Indirect } \\
\text { experience of } \\
\text { nature }\end{array}$} & \multirow{4}{*}{$\begin{array}{l}\text { Fall- } \\
\text { winter }\end{array}$} & 17 & Making fallen leaves cushion & Practical art education & \multirow{2}{*}{ Natural materials } \\
\hline & & 18 & Collecting wasted tissues for mulching & Art & \\
\hline \multirow{2}{*}{$\begin{array}{l}\text { Indirect } \\
\text { experience of } \\
\text { nature }\end{array}$} & & 19 & Making natural diffuser with herb & Practical art education & Natural materials \\
\hline & & 20 & Collecting various shaped seeds & Practical art education & Natural materials \\
\hline
\end{tabular}

Table 8. Result of homogenity test between treatment and control group $(n=24)$

\begin{tabular}{|c|c|c|c|c|c|}
\hline Subordinate variable & Group & M & SE & $\mathrm{t}$ & $p$ \\
\hline \multirow{2}{*}{ Growth environment } & Control & 6.875 & 1.777 & \multirow{2}{*}{-1.634} & \multirow{2}{*}{.109} \\
\hline & Treatment & 6.042 & 1.756 & & \\
\hline \multirow{2}{*}{ Plant division } & Control & 6.875 & 2.092 & \multirow{2}{*}{-0.316} & \multirow{2}{*}{.753} \\
\hline & Treatment & 6.708 & 1.517 & & \\
\hline \multirow{2}{*}{ Integrative thinking increasement } & Control & 7.292 & 2.236 & \multirow{2}{*}{0.626} & \multirow{2}{*}{.535} \\
\hline & Treatment & 7.667 & 1.903 & & \\
\hline \multirow{2}{*}{ Emotional balance } & Control & 6.958 & 3.420 & \multirow{2}{*}{1.240} & \multirow{2}{*}{.221} \\
\hline & Treatment & 8.167 & 3.332 & & \\
\hline \multirow{2}{*}{ Environmental literacy } & Control & 6.208 & 1.834 & \multirow{2}{*}{-1.822} & \multirow{2}{*}{.075} \\
\hline & Treatment & 5.333 & 1.474 & & \\
\hline \multirow{2}{*}{ Humanity increasement } & Control & 11.458 & 4.331 & \multirow{2}{*}{1.751} & \multirow{2}{*}{.087} \\
\hline & Treatment & 13.333 & 2.963 & & \\
\hline \multirow{2}{*}{ Environmental effect } & Control & 7.042 & 2.331 & \multirow{2}{*}{1.532} & \multirow{2}{*}{.132} \\
\hline & Treatment & 8.250 & 3.082 & & \\
\hline \multirow{2}{*}{ Dietary effect } & Control & 5.792 & 2.782 & \multirow{2}{*}{1.252} & \multirow{2}{*}{.217} \\
\hline & Treatment & 6.792 & 2.750 & & \\
\hline
\end{tabular}


Table 9. Result of paired samples t-test of control group $(n=24)$

\begin{tabular}{|c|c|c|c|c|c|}
\hline Questionnaire & Variable & M & SE & $\mathrm{t}$ & $p$ \\
\hline Pre & \multirow{2}{*}{ Growth environment } & 6.875 & 1.777 & \multirow{2}{*}{1.446} & \multirow{2}{*}{.162} \\
\hline Post & & 6.625 & 1.439 & & \\
\hline Pre & \multirow{2}{*}{ Plant division } & 6.875 & 2.092 & \multirow{2}{*}{0.848} & \multirow{2}{*}{.405} \\
\hline Post & & 6.708 & 1.829 & & \\
\hline Pre & \multirow{2}{*}{ Integrative thinking increasement } & 7.292 & 2.236 & \multirow{2}{*}{2.696} & \multirow{2}{*}{$.013^{*}$} \\
\hline Post & & 6.833 & 1.993 & & \\
\hline Pre & \multirow{2}{*}{ Emotional balance } & 6.958 & 3.420 & \multirow{2}{*}{-2.563} & \multirow{2}{*}{$.017^{*}$} \\
\hline Post & & 8.625 & 2.516 & & \\
\hline Pre & \multirow{2}{*}{ Environmental literacy } & 6.208 & 1.474 & \multirow{2}{*}{1.639} & \multirow{2}{*}{.115} \\
\hline Post & & 5.542 & 1.532 & & \\
\hline Pre & \multirow{2}{*}{ Humanity increasement } & 11.458 & 2.963 & \multirow{2}{*}{-2.050} & \multirow{2}{*}{.052} \\
\hline Post & & 13.292 & 3.250 & & \\
\hline Pre & \multirow{2}{*}{ Humanity increasement } & 7.042 & 2.331 & \multirow{2}{*}{-1.584} & \multirow{2}{*}{.127} \\
\hline Post & & 7.833 & 2.792 & & \\
\hline Pre & \multirow{2}{*}{ Dietary effect } & 5.792 & 2.782 & \multirow{2}{*}{-1.149} & \multirow{2}{*}{.262} \\
\hline Post & & 6.583 & 2.858 & & \\
\hline
\end{tabular}

(3) The Results of Pre and Post-experiment Surveys of the Experimental Group

The results of the experimental group showed a statistically significant decrease in the average value of 8 areas (Table 10), and the "curriculum-based programs" seemed to play a very important role. Apart from general knowledge about plants, stress-related areas including "cultivation of character" and "emotional balance," and areas of environmental effects including "environmental literacy" and "integrative thinking ability" showed relatively higher effects than other areas, which indicated that biophilic elements were well expressed and verified the educational effects of the program. In particular, the results of the environment-related areas can be attributed to the fact that various biophilic experience activities including indirect experience of nature (writing a life note, making plant curtains, etc.), activities utilizing images of nature (making a natural sound bell, making a cushion with fallen leaves, etc.) and upcycling natural materials were considered in the program. The results of the stress-related areas can be attributed to the fact that classrooms in schools that had been considered as a learning environment were utilized to perform the program, which reduced participants' psychological burdens of learning. They can be also attributed to the fact that the program was composed to integrate biophilic experience elements into conventional planting-focused horticultural activities, which increased the continuity of the program. On the contrary, there was a relatively smaller difference in the average value of the dietary effect area than other areas. The reason seemed to be that vegetable plants were used, but, unlike general horticultural activities, indirect experience activities based on the biophilic thinking were included only, not direct activities related to dietary life. It also seemed to be difficult to correct the behaviors of 6th graders whose dietary habits were already formed only by applying the horticultural program. Therefore, it will be necessary to consider the necessity for the dietary program in order to improve these effects (Table 10).

(4) The Results of the Post-experiment Survey of the Experimental and Control Groups

The independent sample t-test was performed to compare the results of the post-experiment survey of the experimental and control groups. All areas except the areas of integrative thinking ability showed a statistically significant decrease in 
Table 10. Result of paired samples t-test of treatment group ( $n=24)$

\begin{tabular}{|c|c|c|c|c|c|}
\hline Questionnaire & Variable & M & SE & $\mathrm{t}$ & $p$ \\
\hline Pre & \multirow{2}{*}{ Growth environment } & 6.042 & 1.756 & \multirow{2}{*}{4.371} & \multirow{2}{*}{$.000^{* * *}$} \\
\hline Post & & 5.458 & 1.532 & & \\
\hline Pre & \multirow{2}{*}{ Plant division } & 6.708 & 1.517 & \multirow{2}{*}{5.376} & \multirow{2}{*}{$.000^{* * *}$} \\
\hline Post & & 5.833 & 1.129 & & \\
\hline Pre & \multirow{2}{*}{ Integrative thinking increasement } & 7.667 & 1.903 & \multirow{2}{*}{0.440} & \multirow{2}{*}{$.664^{\mathrm{NS}}$} \\
\hline Post & & 7.625 & 1.789 & & \\
\hline Pre & \multirow{2}{*}{ Emotional balance } & 8.167 & 3.332 & \multirow{2}{*}{3.400} & \multirow{2}{*}{$.002^{* *}$} \\
\hline Post & & 6.750 & 1.847 & & \\
\hline Pre & \multirow{2}{*}{ Environmental literacy } & 5.333 & 1.834 & \multirow{2}{*}{4.891} & \multirow{2}{*}{$.000^{* * *}$} \\
\hline Post & & 3.958 & 1.301 & & \\
\hline Pre & \multirow{2}{*}{ Humanity increasement } & 13.333 & 4.331 & \multirow{2}{*}{3.651} & \multirow{2}{*}{$.001^{* *}$} \\
\hline Post & & 11.125 & 2.473 & & \\
\hline Pre & \multirow{2}{*}{ Humanity increasement } & 8.250 & 3.082 & \multirow{2}{*}{4.046} & \multirow{2}{*}{$.001^{* * *}$} \\
\hline Post & & 6.417 & 2.302 & & \\
\hline Pre & \multirow{2}{*}{ Dietary effect } & 6.792 & 2.750 & \multirow{2}{*}{2.687} & \multirow{2}{*}{$.013^{*}$} \\
\hline Post & & 5.750 & 1.800 & & \\
\hline
\end{tabular}

${ }^{\mathrm{NS}}$ Non-significant, ${ }^{*} p<.05,{ }^{* *} p<.01,{ }^{* * *} p<.001$

Table 11. Result of post test between treatment and control group $(n=24)$

\begin{tabular}{|c|c|c|c|c|c|}
\hline Subordinate variable & Group & M & SE & $\mathrm{t}$ & $p$ \\
\hline \multirow{2}{*}{ Growth environment } & Treatment & 5.458 & 1.532 & \multirow{2}{*}{-2.720} & \multirow{2}{*}{$.009^{* *}$} \\
\hline & Control & 6.625 & 1.439 & & \\
\hline \multirow{2}{*}{ Plant division } & Treatment & 5.833 & 1.090 & \multirow{2}{*}{-2.013} & \multirow{2}{*}{$.050^{*}$} \\
\hline & Control & 6.708 & 1.829 & & \\
\hline \multirow{2}{*}{ Integrative thinking increasement } & Treatment & 7.625 & 1.789 & \multirow{2}{*}{1.448} & \multirow{2}{*}{$.154^{\mathrm{NS}}$} \\
\hline & Control & 6.833 & 1.993 & & \\
\hline \multirow{2}{*}{ Emotional balance } & Treatment & 6.750 & 1.847 & \multirow{2}{*}{-2.943} & \multirow{2}{*}{$.005^{* *}$} \\
\hline & Control & 8.625 & 2.516 & & \\
\hline \multirow{2}{*}{ Environmental literacy } & Treatment & 3.958 & 1.301 & \multirow{2}{*}{-3.859} & \multirow{2}{*}{$.000^{* * *}$} \\
\hline & Control & 5.542 & 1.532 & & \\
\hline \multirow{2}{*}{ Humanity increasement } & Treatment & 11.125 & 2.473 & \multirow{2}{*}{-2.599} & \multirow{2}{*}{$.013^{*}$} \\
\hline & Control & 13.292 & 3.250 & & \\
\hline \multirow{2}{*}{ Environmental effect } & Treatment & 6.417 & 2.302 & \multirow{2}{*}{-1.918} & \multirow{2}{*}{.061} \\
\hline & Control & 7.833 & 2.792 & & \\
\hline \multirow{2}{*}{ Dietary effect } & Treatment & 5.750 & 1.800 & \multirow{2}{*}{-1.209} & \multirow{2}{*}{.233} \\
\hline & Control & 6.583 & 2.858 & & \\
\hline
\end{tabular}

${ }^{\mathrm{NS}}$ Non-significant, ${ }^{*} p<.05,{ }^{* *} p<.01,{ }^{* * *} p<.001$

the average value of the experimental group, and, in particular, the areas of emotional stability and environmental literacy showed a relatively big difference in their average value, which can be attributed to the elements of experiencing biophilic spaces that were continuously provided for the experimental group (Table 11). The reason seemed to be, first, that biophilic horticultural activities were routinely provided by teachers in class for students as a learning program developed after analyzing subjects and units in their curriculum, and, second, that the program was provided from a biophilic aspect for students not only to experience general horticultural activities such as planting, but also to routinely experience 
environments and improve ecological literacy at school. Therefore, it will be very meaningful to provide elementary school students with programs by considering the characteristics of the school-based biophilic program suggested in this study (Table 11).

\section{Conclusion}

This study assumed that experiencing ecological environments and activities using plants for biophilic horticultural activities were effective in enhancing the multi senses of elementary school students. Based on the basic concept of various biophilic design elements and properties, a biophilic horticultural education program was developed by comprehensively analyzing biophilic experience properties and elements, biophilic design elements and properties, biophilic types and eco-friendly design elements in elementary schools that can be connected to ecological education. In addition, related subjects and units were analyzed to increase the on-site applicability of the program. The subjects for 4th, 5th, and 6th graders were analyzed, and biophilic elements were relatively more connected to the subjects for 6th graders such as science, art, social studies, Korean and practical arts. The developed program was composed of a total of 12 sessions, and was directly applied to classes in elementary schools. Among many biophilic experience elements, direct and indirect experiences of nature were selected, but experience of places and spaces was not selected due to limitations in school environments. Indirect experience of nature was mainly composed of handicraft activities (writing a life note, making plant curtains, making a cushion with fallen leaves, making an air freshener with herbs, etc.), and direct experience of nature was composed of activities of directly cultivating plants (water culture, understanding biotop, making an ecosphere, etc.). As a result, biophilic horticultural activities seem to allow people to experience various ecological elements and natural environments together with general horticultural activities, providing a broader range of educational effects than general horticultural activities. The developed program was applied on site, and the following results were obtained. First, the experimental group showed a statistically significant decrease in the average value of all the 8 multisensory areas. In particular, the program was found to be effective in increasing horticultural literacy and improving familiarity with nature and psychological stability. The effects of the program on areas related to stress and environmental effects were higher than other areas, which indicated the biophilic elements within the program were well expressed. On the contrary, there was a relatively smaller difference in the average value of the dietary effect area than other areas. The reason seemed to be that it was difficult to correct the behaviors of 6th graders whose dietary habits were already formed only by applying the horticultural program, and that specific dietary programs or cooking activities were not included in the program. In can be concluded as follows. First, biophilic horticultural activities were routinely provided by teachers in class for students as a learning program developed after analyzing subjects and units in their curriculum. Second, the program was provided from a biophilic aspect for students not only to experience general horticultural activities such as planting, but also to experience environments and ecological literacy at school. Therefore, it will be very meaningful to broadly provide this kind of programs for elementary school students.

\section{References}

Hwang, J.H. and H. Lee. 2015. Biophlic design for psychological healing-Focus on the prospect and refuge in Hyeonghoeru pavillion-. Proc. Korean Inst. Int. Des. Conf. 17(1):47-50.

Jee, H.R. 2015. Development of ecological horticultural activity program for creativity and personality education. Master's thesis, Seoul National University of Education, Seoul, Korea.

Kellert, S.R., J. Heerwagen, and M. Mador. 2008. Biophilic design: The theory, science, and practice of bringing buildings 
to life. Hoboken, NJ: Wiley.

Lee, D.M. and H.S. Lee. 2016. A study of characteristics of sensory richness towards healing environments at the lobby of geriatric hospital using biophilic design approach. J. Korean Inst. Int. Des. 25(3):21-30.

Sim, Y.J. 2008. Analysis of basic elements for connecting environmental education of elementary school. Master's thesis, Seoul National University of Education, Seoul, Korea.

Texas A \& M University. 2010. Junior Master Gardener Handbook. College Station, TX: Author.

Wilson, E.O. 1994. Biophilia. Cambridge, MA: Harvard University Press.

Yoon, J,J. 2013. A study of biophilia representation on integrated service design environment. Master's thesis, Hong Ik University, Seoul, Korea.

Yoon, J.J. and G.H. Lee. 2016. A study of biophilia effect on service design environment. J. Commun. Des. 55:123-138. 